\title{
Performans Yönetiminde Performans Değerlendirme ve Öneri Sitemlerinin Sürdürülebilir Verimliliğe Etkisinin İncelenmesi: Bir Örnek Olay Çalışması ${ }^{1}$
}

\author{
Yrd. Doç. Dr. Hatice SARIALTIN \\ Sakarya Üniversitesi, Sapanca Meslek Yüksekokulu \\ Muhasebe ve Vergi Bölümü \\ hsarialtin@sakarya.edu.tr
}

\section{ÖZET}

Çalışmanın amacı, bir süt ürünleri işletmesinin Performans Yönetimi Sistemi kapsamında gerçekleştirdiği bireysel performans değerlendirme ve öneri sistemi ile sürdürülebilir verimlilik arasındaki ilişki ve etkileşimlerin derinlemesine incelenmesidir. Çalışma, tanımlayıcı ve açıklayıcı nitel bir örnek olay incelemesi olup, veriler anket formu ile yapılandırılmış ve yarıyapılandırılmış yüz-yüze görüşmeler ve doküman inceleme ile sağlanmış, betimsel analiz yaklaşımıyla analiz edilmiştir. Örnek işletmenin sınıfında iyi uygulama örneği olan performans değerlendirme ve öneri sistemini sürdürülebilir verimlilik ile nasıl bütünleştirdiği konusunda literetüre katkı yapabilecek bulgulara ulaşılmıştır. Ayrıca, çalışmanın sonuçları genellenebilir olmasa da, performans yönetim sistemini revize etmek veya mevcut performans sistemlerine sürdürülebilir verimlilik, verimlilik artırma projeleri ve öneri sistemi konularını dahil etmek isteyen işletmeler için uygulanabilir sonuçlara ulaşılmıştır.

Anahtar Kelimeler: Performans Yönetimi, Performans Değerlendirme, Sürdürülebilir Verimlilik, Öneri Sistemleri, Süt Ürünleri İşletmesi.

\section{Examining the Impact of Performance Evaluation and Suggestion Systems of Performance Management on Sustainable Productivity: A Case Study}

\footnotetext{
ABSTRACT

The purpose of the study is to investigate the relationships between individual performance evaluation and suggestion systems with

1 "Bu makale, 23. Ulusal Yönetim ve Organizasyon Kongresinde sunulan bildiriden genişletilerek hazırlanmıştır."
} 
Performans

Yönetiminde

Performans

Değerlendirme

ve Öneri

Sitemlerinin

Sürdürülebilir

Verimliliğe

Etkisinin

İncelenmesi:

Bir Örnek Olay

Çalıșması sustainable productivity and interactions among them in a big-sized dairy products company which has an integrated Performance Management System. Therefore, the study is a descriptive and explanatory qualitative study in nature, and case study method has been used for the research and descriptive analysis approach has been adopted. From this view, a a-three part comprehensive questionnaire has been designed to collect data and responds of the participants have been taken through face-to-face structured and semi-structured interviews and document analysis visiting the business regularly. The study culminates with the findings that would be able to contribute to the literature on how the case organization integrated sustainable productivity with its performance and suggestion systems both are the best in class practices. Although not generalizable, applicable results also have been reached for those who want to revise their performance management systems including sustainable productivity.

Key Words: Performance Management, Performance Evaluation, Sustainable Productivity, Suggestion Systems, Dairy Products Company.

\section{I.GİRIŞ̧}

Sürdürülebilirlik, var olan sınırlı kaynaklarımızı gelecek nesillere yetecek biçimde ve çevreye zarar vermeden kullanarak ve birim maliyetleri düşürerek üretmeye devam etmeyi; yani, en az çevresel etkiyle faktör verimliliğini artırmayı ifade etmektedir (Prokopenko, 1992; MPM, 2004; Prokopenko ve North, 2011). Faktör verimliliğini artırmak bugün pek çok işletmenin temel amacı durumuna geldiğinden dünyanın her yerinde gittikçe artan sayıda işletme ellerindeki kaynakları akılcı biçimde kullanabildikleri iş ve malzeme (mühendislik) teknikleri, kalite ve İnsan kaynakları uygulamaları ve performans yönetimi ve değerlendirme yoluyla Verimlilik Artırma Projeleri (VAP'lar) yürütmektedir (Eksen, 2010; Sarıaltın ve Yılmazer, 2011). Bu bağlamda çalışmanın amacı, büyük ölçekli bir süt ve süt ürünleri işletmesinin Performans Yönetim Sistemi kapsamında gerçekleştirdiği sınıfında iyi uygulama örnekleri olan bireysel performans değerlendirme ve öneri sistemleri ile sürdürülebilir verimlilik arasındaki ilişki ve etkileşimlerin ayrıntılı olarak incelenmesidir.

2000'li yıllardan sonra işletmelerin benimsedikleri Kalite Yönetimi uygulamaları ve diğer global yönetim sistem standartları sayesinde daha da önem kazanan performans ölçme ve değerlendirme, öncelikle İnsan Kaynakları Yönetimi'nin asli görevidir. (Huselid, 1995; Yüksel, 2003; Sabuncuoğlu, 2008, Bingöl, 2014). Diğer taraftan yoğun rekabet ortamında verimlilik ve kar odaklı çalışmak durumunda olan işletmeler için performans ölçme ve değerlendirme süreçleri, aynı zamanda stratejik 
yönetim uygulamalarından biri haline gelmiştir (Dorgan, vd. 2006; Sahu, 2007; Armstrong, 2009; Chubb, vd, 2011; DelCampo, 2011; Dessler, 2013). Nasıl bir performans yönetim sistemi çerçevesinde ölçme-değerleme yapılmalıdır? İşletmenin odaklanması gereken kritik performans alanları nelerdir? Bu performans alanları için performans amaçları ve bunların ölçüm kriterleri neler olmalıdır? Performans sonuçları nasıl değerlendirilmelidir? Performans yönetimi sisteminin sürekliliği nasıl sağlanmalıdır? Bu ve benzeri birçok soru, kaynaklarını olabildiğince etkin ve verimli kullanarak rekabetçi kalmayı hedefleyen bütün yöneticilerin stratejik sorunudur ve çözüm iyi yapılandırılmış performans yönetim sisteminde aranmaktadır (Atılgan, 2002; Sarıaltın, 2003; Dorgan, vd. 2006; Peşkircioğlu, 2014). Performans Yönetimi, organizasyonun neyi başarmak zorunda olduğu hakkında gerekli süreçlerin tespit edildiği ve çalışanların kısa ve uzun vadede bu yönde çalışmalarının ve gelişimlerinin sağlandığ bir süreçtir ve süreçten sadece İK değil, bütün hat yöneticileri sorumludur (Armstrong, 2009: 9-10). Literatürde işletmenin stratejik planında yer alan örgütsel ve bireysel verimlilik hedeflerini hayata geçiren sistemin, yine performans yönetim sistemi veya kurumsal performans yönetimi olduğu açıklanmaktadır (Dorgan vd, 2006; Subramaniam, 2010; Peşkircioğlu, vd. 2013, Aguinis, 2014). Makro düzeyde verimlilik artışlarının mikro (işletme) düzeyde sağlanan artışların toplamı olduğu düşünüldüğünde (Akal, 2011), ülkelerin makro plandaki verimlilik başarısı, ancak işletme odaklı verimlilik artışlarıyla ve sürdürülebilir verimlilik projeleriyle mümkündür.

\section{Literatür İnceleme}

Çalışmaya konu olan işletmenin uygulamalarını inceleyen araştırma deseni (Yin, 2011); Çalışılacak durumun belirlenmesi, araştırmanın ana amacı ve alt amaçların belirlenmesi, araştırmaya katılacak bireylerin seçilmesi ve onay alma, veri toplama aracını (kapsamlı anket) oluşturma, verilerin toplanması, verilerin ana amaç ve alt amaçlarla ilişkilendirilerek analiz edilmesi, analiz bulgularının kavramsallaştırılması ve sonuçların yorumlanması şeklinde tasarlanmıştır. Bütün bu aşamalarda araştırma konusuyla ilgili literatür etkili bir şekilde kullanılmaya çalışılmıştır.

\subsection{Performans Yönetim Sistemi ve Bireysel Performansın Değerlendirilmesi}

Bireysel performans değerlemesi, bireyin görevindeki başarısı, işteki tutum ve davranışları, ahlak durumu ve özelliklerinin objektif ölçütlere göre belirlenmesi sürecidir (Yüksel, 2003: 180; Sabuncuoğlu, 2008: 184; DelCampo, 2011: 122). Uyargil (2013: 3)' e göre ise bireysel performans değerlemesi, bireylerin belirli bir dönemdeki fiili başarı durumları ve

\section{Performans \\ Yönetiminde \\ Performans \\ Değerlendirme ve Öneri \\ Sitemlerinin \\ Sürdürülebilir \\ Verimliliğe \\ Etkisinin \\ Íncelenmesi: \\ Bir Örnek Olay \\ Çalışması}

119 
Performans

Yönetiminde

Performans

Değerlendirme

ve Öneri

Sitemlerinin

Sürdürülebilir

Verimliliğe

Etkisinin

İncelenmesi:

Bir Örnek Olay

Çalıșması

geleceğe ilişkin gelişme potansiyellerini belirlemeye yönelik çalışmalar olarak tanımlanmakta ve çoğunlukla çalışanların üstleri tarafından yılda bir ya da birkaç kez formlar eşliğinde değerlendirilmesini içermektedir. Kalite-verimlilik yaklaşımlarıyla yeniden şekillenen ve bu çerçevede uygulanan performans değerlemesi, bireyin gelişme yeteneğini ve kuruluşun başarısına olan katkılarını değerlendiren ve işletmenin çalışana sağlayacağı eğitim, ödül, geliştirme ve motivasyonun ne olması gerektiğini ortaya koyan planlı bir süreçtir (Armstrong, 2009: 10; Mitchell ve Gamlem: 2012:190; DelCampo, 2011: 122; Dessler, 2013:285). Sahu'ya göre (2007:2), değerlendirme sürecinde dikkate alınan bireysel performans kriterleri; işin gerektirdiği bireysel hedefler ve pozisyonun yüklediği sorumluluklar; işin etkili bir biçimde yapılması için gereken yetkinlikler ve bireyin daha yüksek sorumluluk alma potansiyelidir. Bu perspektiften performans değerlendirme, çalışanın işletmenin stratejik amaçlarlarıyla uyumlu hedefler ve standartlar ile gösterdiği performansın karşılaştırılması, standartlara yaklaştırılması veya gelişme potansiyelinin değerlendirilmesi için gerekli iyileştirme ve geliştirme faaliyetlerinin sistematik olarak gerçekleştirilmesidir (Grote, 2002; Dorgan vd, 2006; Dessler, 2013). Yapılan bu tanımlara bakıldığında, performans değerlendirmeyi statik anlamda bir değerlendirme değil de, dinamik bir süreç olarak ele almak gerekmektedir. $\mathrm{Bu}$ süreçte çalışanların performanslarını planlama, değerlendirme, geri bildirim sağlama ve performans geliştirmeyi amaçlayan ve konuya daha geniş bir açıdan yaklaşan bu örgütsel sistem, performans yönetim sistemi olarak adlandırılmaktadır (Uyargil, 2009: 210). Günümüzde performans değerlendirme denince; bütüncül bir yaklaşımla örgüt, süreç ve bireysel performansın tek bir performans sistemi kapsamında ölçülüp değerlendirilmesini tanımlayan bir performans yönetimi sistemi anlaşılmaktadır ve bireysel performans değerlemesi bu sistemin en temel parçasıdır (Prasetya ve Masanori, 2010: 84; Dessler,2011:357; Mitchell ve Gamlem, 2012: 185; Uyargil, 2013: 3). Performans yönetimi, performans değerlemesinden temelde üç nedenden dolayı farklılık göstermektedir. Birincisi, performans yönetimi yöneticinin astlarla yılda bir kez bir araya gelerek yapılan bir çalışma değil; günlük veya haftalık ast-üst işbirliğinin sürekli olduğu bir süreçtir. İkincisi, her zaman stratejik amaçlara odaklanan bir süreçtir ve bu süreçte, birey ya da takım performanslarının işletmenin stratejik amaçları ile uyumlaştırılması esastır. Üçüncüsü, birey veya takımın işi daha iyi yapması ve performansı artırma konusunda ek bir eğitim veya yeni bir teşvik planı gibi düzenlemelerle performansı tekrar tekrar değerlendirme ve iyileştirmeler devam etmektedir (Dessler, 2011:357-358). Böylece sistem, sadece çalışan bireylerin değil, bütün bir organizasyonun stratejiye ve sürekli ölçme-iyileştirmeye dayalı olarak nasıl 
çalıştığını değerlendirmektedir (Sarıaltın, 2003; Chubb, vd. 2011). Performans yönetimi sistemi, amaçlara göre yönetimi ve geleneksel performans değerlemesini bütünleştiren bir stratejik bir yönetim sürecidir (Armstrong, 2009:10; DelCampo, 2011:128). Ayrıca, çalışanların performans düzeylerini değerlendiren ve belgelendiren bir performans yönetimi sistemi, terfi ya da işten çıkarma kararları için de yasal bir gereklilik olmuştur (Adal, 2009: DelCampo, 2011; Bingöl, 2014).

\subsection{Performans Yönetimi ve Sürdürülebilir Verimlilik İlişkisi}

Günümüzde tüketimin ve buna koşut olarak üretimin hızla artması sonucu ortaya çıan küresel 1sınma, iklim değişiklikleri vb. çevresel sorunlar "sürdürülebilirlik" ve "verimlilik" kavramlarının birlikte düşünülmesini gündeme getirmiştir. Buna göre verimlilik kavramı artık çıtılarla girdiler arasındaki oransal ilişkiyi açılayan bir kavram olmaktan çok; insana ve çevreye saygı ve sürdürülebilirlik esaslarını da içermektedir.

Bu bağlamda, verimliliğin "doğru ürün ya da hizmeti beklenen kalitede, doğru zamanda, çevreye zarar vermeden en az maliyetle üretmektir" şeklinde daha geniş ve nitel tanımları yapılarak (Koç, 2009; Hesapro, 2013), sürdürülebilir verimliliğe dikkat çekilmektedir. Sürdürülebilir verimlilik, kaliteli ve güvenilir ürünleri minimum çevresel etkiyle üretme, müşterilerle sürekli işbirliği içinde olma, çalışanlara iyi bir çalışma ortamı sağlama, enerji verimliliğini artırma, tedarikçileri destekleyen projeler gerçekleştirme ve topluma yönelik sosyal sorumluluk faaliyetlerinin içinde olma çabalarının tümüdür. Diğer bir ifadeyle sürdürülebilir verimlilik, başta insan kaynakları ve doğal kaynaklar olmak üzere üretim faktörlerini yüksek bir toplumsal sorumluluk bilinciyle kullanarak kaliteli, güvenilir ve çevreye duyarlı ürün ve hizmet üretmeye devam etmektir (Prokopenko, 1992; Prokopenko ve North, 2011; Sarıaltın ve Yilmazer, 2011).

1990'l1 yıllardan itibaren işletmeler, verimlilik artırma ve kalite yönetimini birlikte ele almaya başlamış ve daha geniş verimlilik yaklaşımlarıyla; verimlilik artırma teknikleri ve projeleri uygulayarak faktör verimliliğini artırmaya odaklanmıştır (MPM, 1999; Koç, 2009; Forfas, 2009). Araştırmacı ve uygulayıcıların da tespiti kalite performansı ile verimlilik arasında önemli ölçüde pozitif bir ilişki olduğu yönündedir (Kontoghiorghes ve Gudgel, 2004; Verimlilik Genel Müdürlüğü, 2012; WCPS, 2012). Ayrıca, kaynakları etkin kullanarak sağlanan verimlilik artışının uzun vadede karlılığı da olumlu etkilediği açıklanmaktadır (Tangen, 2005: 40). Yine, literatürde bireysel performans değerlemesini, ödüllendirmeyi ve kariyer gelişimini içeren bir performans yönetiminin verimliliğin yanı sıra müşteri tatminini ve pazar payını artırdığı açıklanmaktadır (Dorgan vd, 2006; 
Performans

Yönetiminde

Performans

Değerlendirme

ve Öneri

Sitemlerinin

Sürdürülebilir

Verimliliğe

Etkisinin

İncelenmesi:

Bir Örnek Olay

Calıșması

Duchon, 2007; Prasetya ve Masanori, 2010). Sonuçta, bir işletmede verimliliği artırmak ve bu artışı sürdürmek yönetim işlevinin temel sorumluluğudur, iyi yönetimle eş anlamlıdır (Akal, 2011).

Hiçbir kural tanımadan bilinçsizce yapılan tüketimi karşılayabilmek için yapılan üretimin eko sistemin yeniden üretme ve özümseme kapasiteleri dahilinde yapılması, yani sürdürülebilir olması zorunludur. (Prokopenko, 2006; Aktaran, Hekimci, 2012). Sürdürülebilirliği iş modellerinin kalbine koyan işletmeler için sürdürülebilir verimlilik; kaynakları israf etmeden, daha az kaynak kullanarak kaliteli ve güvenilir ürünler üretmeye devam ederken, çevre dostu yenilikçi ürünler geliştirme, çalışanların performansını artıran ve bireysel gelişimlerini destekleyen çalışma ve yönetim ortamı sağlama, işgücü, hammadde, sermaye ve enerji verimliliğini artıran projeler gerçekleştirme ve sosyal sorumluluk üstlenme çabalarını kapsayan bir çalışma ve yaşama tarzıdır (Atlas COPCO, 2009; Arçelik, 2014; Borusan, 2014).

İşletmelerin iş ve yönetim süreçlerinde mevcut stratejilerini, politikalarını ve planlarını hayata geçiren kilit yönetim uygulaması, yüksek performansa odaklanan performans yönetim sistemidir (Aguinis, 2014:17; Dessler, 2013:285). Performans yönetim sisteminin yüksek performans, kalite ve verimlilik kültürü oluşturmada pozitif etkisi olduğunu vurgulayan çalışmalara (Çalışkan, 2010; Chen, vd. 2016; Saratun, 2016) göre sistem; hiç olmazsa işgörenle performans anlaşması yapmayı, sürekli geribildirimi ve performans değerlendirmeyi kapsamalıdır.

Bir üst amaç olan sürdürülebilirliğin sağlanmasında verimlilik ilkelerine göre yönetimi öngören performans yönetimi, yalnızca kaynakların doğru kullanılmasını değil, doğru işin yapılmasını sağlayan ölçümlerle de kuruluşta gelecekte olmak istenen yer ve bu yere ulaşmak için gereken stratejilerin uygulanmasını sağlamaktadır (Tümer, 2007: 24). Literatür incelemesine göre, performans değerlendirme ile verimliliği ilişkilendiren çalışmaların 2000'li yılların ortalarında artmaya başladığı görülmektedir (Tangen, 2005; Dorgan vd, 2006; Duchon, 2007). 2007 y1lından günümüze kadar verimlilik ile performans yönetimi ve performans değerlendirme ilişkisini daha spesifik olarak inceleyen bazı çalışmalar olduğu görülmektedir (Prasetya ve Masanori, 2010; Subramaniam, 2010; Zaman, 2011; Speziale ve Kloviene, 2014; Saratun, 2016). Türkçe yazında, konuyla ilgili yüksek lisans ve doktora çalışmalarının 2005 yılından sonra başladığı (Yılmaz, 2006; Özbek, 2007; Özen, 2008; Çömlek, 2009), sayıları az da olsa bu çalışmalarda verimlilik ile performans ilişkisinin incelendiğ görülmektedir. 


\section{Performans Değerlendirme ve Öneri Sistemine İlişkin Analiz}

$\mathrm{Bu}$ bölümde araştırmanın amacı ve cevap aranan araştırma soruları, araştırmanın yöntemi, örneklem, veri toplama süreci ve veri analizi, kullanılan anketin yapısı ve içeriği ile araştırma kısıtları açıklanmaktadır.

\subsection{Araştırmanın Amacı ve Araştırma Soruları}

Araştırmanın amacı, bir süt ürünleri işletmesinin Performans Yönetimi Sistemi kapsamında gerçekleştirdiği bireysel performans değerlendirme ve öneri sistemlerinin sürdürülebilir verimlilik ile ilişki ve etkileşimlerinin ne düzeyde ve nasıl olduğunu konuyla ilgili ilişkilendirmeler ve örüntüler dâhilinde derinlemesine incelemektir. Çalışma, konuyu kendi çerçevesi içinde ve sebep-sonuç ilişkisine dayanarak bütüncül olarak sunmak üzere tasarlanan tanımlayıcı ve açıklayıcı bir örnek olay incelemesidir (holistic single case study) ve aşağıdaki soruların cevapları aranmaktadır:

1. Örnek işletme için sürdürülebilir verimlilik ne anlama gelmektedir ve VAP'ları nelerdir?

2. Performans yönetimi sürecinde, performans değerlendirme ve öneri sisteminin sürdürülebilir verimlilik ile ilişkisi nasıl kurulmuştur?

3. Performans yönetimi sistemi ve öneri sistemi sürdürülebilir verimliliği nasıl etkilemektedir?

4. İşlem adımları, ilişkilendirmeleri, prosedürleri, değerleme yöntemleri ve sonuçları bakımından verimlilik temelli bir performans yönetimi, bireysel performans değerlemesi ve öneri sistemi nasıl uygulanmaktadır?

Çalışma, bireysel performans değerlemesini, bireysel önerileri ve verimlilik hedeflerini içeren bir performans yönetimi sistemine yönelik verileri kendi zenginliği ve derinliğinde inceleyerek "sürdürülebilir verimliliğe" dikkat çekmekte ve bunu sağlayabilen bir performans yönetiminin nasıl uygulandığına açıklık getirmektedir. Bu itibarla araştırma sonuçlarının literatüre katkı sağlayabileceği ve pratiğin içinde olan bireyler için uygulanabilir sonuçlarlar olabileceği düşünülmektedir. Nitel araştırmalarda araştırmacı, topladı̆̆ konusunun teorik çerçevesini kullanarak; özelden genele, parçadan bütüne doğru bir akıl yürüterek kavramsal ilişkilendirmeler ve yorumlar yaparak uygulanabilir sonuçlara ulaşabilir (Baxter ve Jack, 2008).

\subsection{Metodoloji}

Araştırma, büyük ölçekli bir süt ürünleri imalat işletmesinin performans yönetim sistemi kapsamında uyguladığı bireysel performans
Performans

Yönetiminde

Performans

Değerlendirme ve Öneri

Sitemlerinin

Sürdürülebilir

Verimliliğe

Etkisinin

İncelenmesi:

Bir Örnek Olay

Çalışması

123 
Performans

Yönetiminde

Performans

Değerlendirme

ve Öneri

Sitemlerinin

Sürdürülebilir

Verimliliğe

Etkisinin

İncelenmesi:

Bir Örnek Olay

Çalıșması değerlendirme ve öneri sistemlerinin sürdürülebilir verimlilik ile ilişki ve etkileşimlerini tam anlamıyla anlamaya ve açıklamaya çalışan nitel bir araştırmadır. Yorumlayıcı yaklaşıma dayanan nitel araştırma, görüşme, gözlem ve doküman analizi gibi veri toplama yöntemlerinin kullanıldığı, olgu ve olayların kendi doğal ortamları içinde gerçekçi bir şekilde ortaya konmasına yönelik nitel bir sürecin izlendiği araştırmadır. Bu süreçte "neden" ve "nasıl" sorularının cevapları için öncelikli olarak araştırma konusu ön plandadır (Altunışık vd, 2004; Yıldırım ve Şimşek, 2005; İslamoğlu ve Alnıaçı, 2014). Bilgi toplama sürecine aktif olarak katılan araştırmacı, cevaplayıcılarla yüz-yüze derinlemesine görüşmüş ve tümevarımcı bir yaklaşımla ayrıntıları yakalamaya çalışarak araştırma sonuçlarını bu yaklaşımla yorumlamıştır.

Araştırmanın Örneklemi: Araştırmacının önceki bilgi ve deneyiminden hareketle, kurumsallaşmış bir performans yönetimi sistemi, öneri sistemi ve verimlilik artırma projeleri olduğu bilinen örnek işletme, amaçlı olarak seçilmiştir. Kasti ya da amaçlı örnekleme, nitel araştırmalarda tercih edilen bir örnekleme türüdür. Tercih nedeni, zengin bilgiye sahip olduğu düşünülen durumların derinlemesine çalışılmasına olanak vermesidir (Yıldırım ve Şimşek, 2005).

Yöntem: Araştırmada, performans yönetimi ve öneri sistemlerinin sürdürülebilir verimlilik ile ilişki ve etkileşimlerini işletme düzeyinde derinlemesine inceleyerek, konuları ve bağlantılarını detaylı bir şekilde tasvir edip açıklamak amaçlandığı için "örnek olay yöntemi” kullanılmıştır. Nitel araştırma desenlerinden biri de örnek olay çalışmasıdır. Örnek olay, kişisel bir araştırma yöntemi olarak belirli bir olguya, duruma veya sürece kendi çerçevesi içinde konsantre olmaya ve birbirini etkileyen prosesleri belirleyip, verileri sebep-sonuç ilişkisine dayanarak açılamaya elverişli bir yöntemdir (Altunışık, vd, 2004:224). Araştırma konusu hakkında iki ay boyunca sistematik araştırmanın yürütüldüğü bu çalışma; ne, niçin, nasıl sorularına cevaplar bulmak amacıyla konuyla ilgili bütün değişkenlerin karşılıklı etkileşimlerinin incelendiği tanımlayıcı ve açıklayıcı bir örnek olay incelemesidir (Baxter ve Jack, 2008).

Veri Toplama ve Veri Analizi: Veri toplamada bireysel görüşme ve doküman inceleme yöntemlerinden yararlanılmıştır. Araştırma, Genel Müdürden ve katılımcılardan onay alındıktan sonra Şubat-Nisan 2015 tarihleri arasında yürütülmüştür. Üç̧ ayrı işletme ziyaretinde gerçekleştirilen görüşmelerde üç bölümden oluşan ve 56 açı uçlu soruyu içeren anket uygulanmıştır (EK,1). Anket hazırlama sürecinde anketin ana bölümleri belirlenmiş, bu bölümlerin altında açık uçlu sorular oluşturulmuştur. İşletmede gerçekleştirilen yapılandırılmış ve yarı 
yapılandırılmış görüşmeler, bu sorulardan hareketle yapılmıştır. Derinlemesine görüşmelere dayalı bu araştırmada sorular, eleştirel kaynak inceleme ve kavramsal çerçeveyi oluşturma sürecinde önceden hazırlanmakla birlikte, hiç düşünülmemiş bazı sorular görüşmeler esnasında ortaya çıkmış ve araştırmaya dahil edilmiştir.

Ayrıca, araştırmanın veritabanını zenginleştirmek amacıyla örnek işletmenin İK Politikası, Performans Yönetimi Yönetmeliği, Performans Yönetimi Süreç Akış Şeması, Performans Değerlendirme ve İşgücü Öneri Formları incelenmiş ve doküman bilgileri, araştırma sorularına göre önceden belirlenen temaların; yani cevapları aranan temel konuların analizine dahil edilmiştir. Katılımcıların sözlü ifadelerinin araştırma konusuyla ilgili dokümanların içerdiği bilgilerle karşılaştırılması, elde edilen verilerin geçerliliği açısından önemlidir.

Veri Analizi: Elde edilen veriler okunup düzenlendikten sonra araştırma sorularına göre önceden belirlenmiş olan temalar halinde gruplandırılarak betimsel bir yaklaşımla analiz edilmiştir. Esasen nitel araştırmalarda veri toplama, veri analizi ve sonuç çıkarma aynı zamanda gerçekleştiğinden, veri analizi araştırmanın başından sonuna kadar devam eden bir süreçtir. Neuman'a göre (2014), araştırmacı veri toplama sürecinde belli aralıklarla toplanan verilere bir açıklık getirmeye çalışır ve varsa eksik bilgilere yönelir ya da açılanan konuları teyit etmeye yarayacak verileri toplamaya devam eder. $\mathrm{Bu}$ araştırmada da genelde betimsel analiz benimsenmiş olsa da, özelde veriler kendine has bir üslupla analiz edilmiştir. Buna göre, ilk görüşmelerde elde edilen veriler okunup etüd edilerek analiz edilmiş ve hangi verinin hangi temanın altında yer alacağına karar verilmiştir. $\mathrm{Bu}$ aşamada hangi verilerin önemli olduğu ve hangilerinin dişlanabileceği katılımcılarla e.postalarla teyitleşerek belirlenmiş ve ikinci görüşme öncesi bir sadeleştirme yapılmıştır. İkinci ve üçüncü görüşmelerden elde edilen verilerin analizi için de aynı yol izlenmiş ve katılımcılarla gerek görüşmeler esnasında gerekse analiz sürecinde sürekli teyitleşerek gerekli-gereksiz veriler ayıklanıp sadeleştirme yapılmış ve ulaşılan bulgular katılımcı ifadelerinden alıntılarla desteklenmiştir.

Analiz sürecinde veriler, katılımcılarla sürekli teyitleşerek yeniden değerlendirme ve tanımlamalara, sadeleştirme ve özetlemelere tabi tutulmuş ve bulgulara dönüştürülmüştür.

Araştırmada Kullanılan Anket Formu: Hazırlanan anket, araştırma konusuyla ilgili olarak cevaplayıcıların bilgi, deneyim ve değerlendirmelerini anlamaya çalışan ve konuyu kendi bütünlüğü içinde sorgulayan bir veri toplama aracı olarak tasarlanmıştır. Anket içeriğinin

\section{Performans \\ Yönetiminde \\ Performans \\ Değerlendirme ve Öneri \\ Sitemlerinin \\ Sürdürülebilir \\ Verimliliğe \\ Etkisinin \\ Íncelenmesi: \\ Bir Örnek Olay \\ Çalışması}

125 
Performans

Yönetiminde

Performans

Değerlendirme

ve Öneri

Sitemlerinin

Sürdürülebilir

Verimliliğe

Etkisinin

İncelenmesi:

Bir Örnek Olay

Çalıșması

tasarlanması ve soruların hazırlanmasında, İK literatüründen (Huselid, 1995; Grote, 2002; Yüksel, 2003; Armstrong, 2009; Sabuncuoğlu, 2008; Uyargil, 2013; Dessler, 2013) ve performans yönetimi ile verimlilik ilişkisini inceleyen kaynaklardan yararlanılmıştır (Prokopenko, 1992; Dorgan vd, 2006; Sahu, 2007; Prasetya ve Masanori, 2010; Subramaniam, 2010).

Anketin 14 sorudan oluşan birinci bölümünde katılımcllardan sürdürülebilir verimliliğin ne anlama geldiği, performans değerlendirme ve performans yönetimi ile bağlantısını açıklayan veriler sağlanmıştır. İşletmenin kalite yönetimi uygulamaları, sahip olduğu sistem belgeleri, genel yönetim sistemi, kalite, İK, çevre politikaları, verimlilik artırma projeleri ve performans yönetim sisteminin amaç ve kapsamını sorgulayan sorularla araştırmaya bir altyapı oluşturmak istenmiştir. İkinci bölümde; performans yönetiminin, nasıl uygulandığı ve aşamaları, sürdürülebilir verimlilik ile ilişki ve etkileşimleri, performans değerlendirme periyodu ve kullanılan yöntem, performans geribildirimleri, performans sonuçlarının kullanımı ve performans sisteminin diğer sistemlerle entegrasyonu konularında detaylı bilgiler sağlayan ve görüşmeler esnasında bazıları yeni eklenen veya tekrar sorulan 33 soru yer almıştır. Üçüncü bölümde, bireysel öneri sisteminin ne anlama geldiği, nasıl uygulandığı, sürdürülebilir verimlilik ile ilişkisi ve performans yönetim sistemiyle bağının nasıl kurulduğu hakkında 9 soru yer almıştır. Anket içeriğine göre toplanan veriler, araştırma sorularına göre belirlenen temalara göre gruplandırılarak düzenlenmiş, betimsel analizlerle sadeleştirilerek anlamlandırılmış ve bulgulara dönüştürülmüştür.

Anketin uygulandığı katılımcılar İK Müdürü, Kalite Güvence Müdürü, VAP Koordinatörü, Bakım Müdürü ve kalite mühendisinin işletmede çalışma süreleri ortalama 9 yıl, mevcut pozisyonlarda çalışma süreleri ise ortalama 5 yıl olup, tüm katılımcılar üniversite mezunudur.

Araştırmanın Sınırlılığı: Çalışma, örnek olay kapsamında yer alan işletmenin performans yönetim sistemi içerisinde yürütülen bireysel performans değerlendirme ve öneri sisteminin incelenmesiyle sinırlıdır ve pek çok nitel araştırmada olduğu gibi, bu örnek olay incelemesinde de katılımcı sayısı görece olarak düşük olmuştur. Ayrıca, işletmede sürdürülen görüşmeler, doküman inceleme ve katılımclarla analiz bulgularını sürekli teyitleşme süreci, zaman kısıtı nedeniyle iki ayda tamamlanmıştır. İşletmenin adının gizli tutulması da, araştırmacının işletmeye özgü kavram ve detayları özgürce kullanmasını kısıtlayan diğer bir faktör olmuştur.

\section{Bulgular}


Görüşmeler ve doküman incelemeyle sağlanan detaylı veriler, makale metninde birinci tema bulguları olarak 9 alt grupta; ikinci tema bulguları olarak 12 alt grupta; üçüncü tema bulguları olarak da 2 alt grupta özetlenmiştir. Ulaşılan bulgular; işletmenin performans yönetimi, performans değerlendirme ve verimlilik altyapısı; performans yönetim sisteminin işleyişi, aşamaları, sonuçları ve sürdürülebilir verimlilik ile ilişkisi; bireysel öneri sisteminin işletme için anlamı ve sürdürülebilir verimlilik ile ilişkisi başlıkları altında açıklanmaktadır.

\section{1.İşletmenin Performans Yönetimi ve Performans Değerlendirme Sistemi ve Verimlilik Altyapısı}

İşletmenin Sahip Olduğu Yönetim Sistem Belgeleri: TS EN ISO 9001: 2008 Kalite Yönetim Sistem Standardı, TS EN ISO 22000 Gıda Güvenliği Sistem Standardı, ISO 14001 Çevre Yönetimi Sistem Standardı ve OHSAS 18001 Çalışan Sağlığı ve İş Güvenliği Sistem Standardı belgelerine sahip olan işletme, TKY uygulamalarına 2005 yılında başlamış ve sözü geçen yönetim standartlarını kalite yönetimi sistemine 2007 yılında entegre etmiştir.

İşletmenin Genel Yönetim Sistemi: TS EN ISO 9001 Kalite Yönetim Sistem Standardı ile TS EN ISO 22000 Gıda Güvenliği Sistem Standardı'nı birbirine entegre eden; çevre yönetimi ile iş sağlığı ve güvenliği (ISG) yönetiminin gereklerini de hayata geçiren işletmede entegre yönetim sistemi (EYS) mevcuttur. İşletme, EYS'de var olan ve bütün süreçlerine, birimlere, takımlara ve faaliyetlerine yayılmış olan verimlilik artırma projeleriyle sürdürülebilir verimlilik için çabalayan büyük ölçekli bir süt ürünleri imalat işletmesidir. İşletmenin yazılı misyon ve vizyon bildirimleri, kalite, çevre ve İSG politikaları mevcut olup, işletmede stratejik planlama yapılmaktadır. Bilgi sistemi üzerinden ilgili kişi ve birimlerin eş zamanlı olarak kullanabildiği stratejik planları, iş planları, departman programları, süreç akış ve ürün planları, yazılı prosedürler ve iş talimatları mevcuttur.

İşletme İçin Sürdürülebilir Verimliliğin Anlamı: İşletmede, kalite ve gida yönetimi standartları doğrultusunda faktör verimliliğini artırarak büyümek temel bir stratejidir ve bu stratejinin gereği olarak dokuz yıldır VAP'lar uygulanmaktadır. VAP koordinatörü ve İK yöneticisi sürdürülebilir verimliliğin anlamını şöyle açılamaktadır: "Ulusal, bölgesel ve dünya pazarlarında yüksek kalite standartlarında ve rekabetçi fiyatlarla gıda üreterek varlığını sürdürebilmek ve gıda güvenliğini să̆lamak (çĭ̆ sütün güvenli ve sürdürülebilir kullanımı) ve VAP stratejilerimizin bir gereği olarak sürdürülebilir verimlilik anlayışı, genel yönetim sistemimizin operasyonel temel taşıdır". İşletmenin verimlilik anlayışına göre global piyasalarda rekabetin ve yüksek kalitenin ön koşulu verimliliktir. Bu nedenle, işletmenin faktör 
Performans

Yönetiminde

Performans

Değerlendirme

ve Öneri

Sitemlerinin

Sürdürülebilir

Verimliliğe

Etkisinin

İncelenmesi:

Bir Örnek Olay

Çalıșması

verimliliği ile ilgili performans hedefleri, performans yönetim sistemi içinde KPI'lar olarak yer almaktadır.

İşletmenin Verimlilik Stratejisi: Örnek işletme, TS EN ISO 9001 Kalite - ve TS EN ISO 22000 Gıda Güvenliği Yönetim Sistemi kapsamında bütün süreçlerine, birimlere, takımlara ve bireylere yayılmış olan faktör (işgücü, hammadde, makine-ekipman, enerji) verimliliğini artırma projeleriyle sürdürülebilir verimliliği genel yönetim sisteminin ana felsefesi ve operasyonel temel taşı olarak görmektedir. İşletmenin genel yönetim sürecinde proje takımları aracılığı ile bütün süreçlerine ve departmanlara yayılmış olan $\mathrm{VAP}^{\prime}$ larından bazıları; makine ekipman verimliliğini ve ilgili işgücünün yetkinliklerini artıran Otonom Bakım Sistemi; enerji verimliliği projeleri olan Kondens Geri Kazanım Projesi ve Anaerobik Arıtma Projesi; hammadde (çĭ̆ süt) tedarikinde sürdürülebilir kaynak verimliliğini esas alan Burdur Projesi, işletmenin geneli için proje bazında çalışan Motivasyon Takımı ve Akıl Küpü Öneri Sistemidir.

İşletmenin Performans Yönetim Sistemi: TS EN ISO 9001 Kalite ve TS EN ISO 22000 Gıda Güvenliği Yönetim Sisteminin bir gereği olarak işletmede 2006 yılından beri uygulanan bir performans yönetim sistemi mevcuttur. Kurumsal düzeyde uygulanan sistemin resmi adı: Performans ve Kariyer Yönetim Sistemi (PKYS)'dir. Kullanılan performans ölçme-değerlendirme yöntemi ise, hedef ve yetkinlik bazlı değerlendirme yöntemidir.

Performans ve Kariyer Yönetim Sistemi"nin Amacı ve Kapsamı: Sistemin temel amac1, yüksek performans kültürü oluşturmaktır. PKYS, vizyonu ve ana hedefleri organizasyona taşımak için gerçekleştirilen kilit bir yönetim uygulaması ve organizasyonun kariyer planlaması için de somut bir göstergedir. Organizasyonu oluşturan bireylerin, takımların ve süreçlerin sürekli iyileştirilmesi ve geliştirilmesi açısından genel yönetim süreci olan PKYS, performans-ödül-disiplin dengesi açısından da temel bir İnsan Kaynakları uygulamasıdır.

Sistemin Kapsamı: Sitemin kapsama alanı bütün çalışanlardır. Diğer bir ifadeyle PKYS, işletmenin bütününe yönelik bir yönetim uygulamasıdır. Bu uygulama, her yıl Ocak Ayı başında vizyona ve stratejik amaçlara göre saptanan hedefleri departman hedeflerine; departman hedeflerini de birey hedeflerine indirgeyen "ortak hedef" sistemine göre gerçekleştirilmektedir. İşletmenin iş, yönetim ve destek süreçleri tanımlı olduğu için, birden fazla departmanı, takımı veya bireyi ilgilendiren ortak hedefler, pek tabidir ki bazı yönetici ve/veya çalışanların da ortak hedefleri olabilmektedir. Katılımcılar, sistemi kapsam açısından şöyle açıklamaktadır: "PKYS, her yılın başında vizyon doğrultusunda makrodan mikroya hedef, görev ve 
sorumluluklar bazında indirgenen; değerlendirme sonucunda da bireyden - birime birimden - kuruma doğru işleyen bütüncül bir süreçtir. Aralık Ayında performans değerlendirme sonuçları açısından büyük resme bakıldığında; bireyden-birime ve birimden-kuruma, toplam örgütsel performansı görebilirsiniz". Sistem, beyaz yaka-mavi yaka ayırmaksızın bütün çalışanları kapsadığı gibi, mevcut süreçleri ve departmanları da kapsamaktadır. Böylece kurumsal performans ve bireysel performanslar tek bir sistem kapsaminda yönetilmektedir.

Üst Yönetimin Performans Yönetim Sistemine Desteği: Genel Müdür ve üst yönetim ekibinin performans yönetiminin uygulanması, gereklerinin yerine getirilmesi ve sürdürülmesi konusundaki desteği ve kararlılığ tamdır. Ayrıca, işletmenin bağlı bulunduğu holding bünyesindeki IKK Koordinatörlügünce dünyadaki yeniliklere ve trendlere göre sürekli desteklenen sistem, kendi prosedürü doğrultusunda uygulanmaktadır.

4.2. Performans ve Kariyer Yönetim Sisteminin İşleyişi, Aşamaları, Sonuçları ve Sürdürülebilir Verimlilik İle İlişkisi

PKYS'nin İlişkili Olduğu Birimler ve Bireyler: İşletmenin İK departmanı performans yönetim sürecinin sahibidir. İK yöneticisi, genel müdür, süreç ve departman müdürleri de sürecin sahibidir. Performans sisteminin düzenliliği ve sürekliliğinden bütün hat yöneticileri sorumludur. Sistemin sağlıklı bir şekilde işlemesinden ise, yukarıdan aşağıya bütün çalışanlar sorumludur. IKK yöneticisi ve hat yöneticileri performans bilgisini toplamaktan sorumludur. Performansla ilgili bilgilerin sistemdeki formlara girilmesinden departman yöneticileri sorumludur. İK yöneticisi bu süreci takip ve kontrol etmektedir.

Sistemde Bilgi Akışı: İşletmede bütün sistemleri, süreçleri, departmanları, takımları ve bireyleri birbirine bağlayan entegre bilgi (SAP) sistemi ve bu sistem üzerinden çalışan etkin bir raporlama sistemi mevcuttur. Performans yönetimi, bu sistem üzerinden işlemekte ve eş zamanlı ve hızlı bir bilgi akışı sağlamaktadır. Yöneticiler ve çalışanlar, performans ile ilgili hedef belirleme, ara değerlendirme ve nihai değerlendirme bilgilerini SAP üzerinden ilgili formlar yardımıyla sisteme girmekte ve paylaşmaktadır. Performans raporlama, SAP üzerinden ilk amir, İK yöneticisi, ilgili süreç/departman yöneticisi ve üst yönetime aynı anda ulaşmaktadır.

Performans Değerlendirmenin Sürdürülebilir Verimlilik İle İlişkisi: Performans ve kariyer yönetimi kapsamında gerçekleştirilen performans değerlendirme süreci sürdürülebilir verimlilik ile bire-bir ilişkilidir. İşletmenin vizyonu doğrultusunda temel stratejilerinden biri de VAP stratejisidir. Bu strateji birime indirgendiğinde birimin verimlilik hedefleri
Performans

Yönetiminde

Performans

Değerlendirme ve Öneri

Sitemlerinin

Sürdürülebilir

Verimliliğe

Etkisinin

Íncelenmesi:

Bir Örnek Olay

Çalışması

129 
Performans

Yönetiminde

Performans

Değerlendirme

ve Öneri

Sitemlerinin

Sürdürülebilir

Verimliliğe

Etkisinin

İncelenmesi:

Bir Örnek Olay

Çalıșması

aynen ilgili çalışanın da verimlilik hedefleri haline gelmekte ve birey günlük görev ve sorumluluklarını yerine getiriyorken aslında verimlilik odaklı çalışmaktadır. Diğer bir ifadeyle, performans yönetim sisteminin içerisinde verimlilikle ilgili KPI' lar yer almakta ve izlenmektedir. İşletmenin kaynakları etkin kullanma, sürdürülebilir maliyetler ve kalitenin ön koşulu olarak belirlediği verimlilik göstergeleri: İşçilik maliyetleri, müşteri memnuniyetinde yüzde artış, işgücü kayıpları, hatalı ürün yüzdesi, eğitim saati, malzeme, makine-hat verimliliği hedefleri, çalışan memnuniyeti, enerji verimliliği hedefleri ve akıl küpü öneri sistemi hedeflerine göre belirlenmektedir.

Performans ve Kariyer Yönetim Sisteminin Uygulama Aşamaları: Sitem, yıl boyunca üç aşamada gerçekleştirilmektedir. Birinci aşama Ocak Ayı planlama aşamasıdır. İkinci aşama Temmuz Ayında gerçekleştirilen ara değerlendirmelerdir. Üçüncü aşama Aralık Ayında yapılan performans değerlendirme, geribildirim ve performans geliştirme aşamasıdır.

Planlama Aşaması: Yılın başında stratejik planlama doğrultusunda yıllık şirket hedefleri belirlenmektedir. Bu noktada İK departmanı sahipliğinde tüm hat yöneticilerinin katıldığı bir "hedef çalıştayı" düzenlenip, hat yöneticilerinin ortak kararları ile şirket KPI'ları belirlenmektedir. Bu çalıştayda tüm KPI'lar vizyonu ve stratejik hedefleri hayata geçirmek üzere ve bölümler arası çatışmaya mahal vermeyecek şekilde saptanmaktadır. Böylece yeni yıl için şirket ana hedefleri belirlenmekte ve ana hedefler SAP üzerinden tüm çalışanlarla paylaşılmaktadır. Sonrasında her departman, saptanan KPI'ları referans alarak kendi hedeflerini belirlemekte ve üyelerinin hem fikir olduğu departman hedeflerini ve bireysel hedefleri SAP sistemi üzerinden üst yönetime sunmaktadır.

Ara Değerlendirme Aşaması: Mutabakata dayalı ara değerlendirmede çalışanlarla departman yöneticileri, hedeflerin gerçekleşme durumunu ve hedeflerle ilgili şu anda varılan noktayı değerlendirmektedir. Bu nedenle ara değerlendirme, yönetici ile çalışanın karşılıklı olarak hedeflerde mutabık kalmaya çalıştıkları ciddi bir süreçtir. Çalışan, yılın başında koyduğu bireysel hedefleri ve diğer hedefler konusunda ya yöneticiyi ikna etmekte; ya da yönetici onu ikna etmekte ve mutabakat sağlanmaktadır. Buna göre; her çalışan yılın başında belirlenen hedeflerinde geldiği son durumu yöneticisine sunmakta, sonra da yönetici, çalışanın hedefler göre gösterdiği performansa yönelik değerlendirmesini sisteme girmektedir. Daha sonra çalışan hedeflerle ilgili neler yaptığını değerlendirip sisteme girmektedir. 
Yılsonu Değerlendirme Aşaması: Aralık Ayında her departman kendi içinde hedeflerle ilgili gelinen son noktayı değerlendirmektedir. $\mathrm{Bu}$ aşamada, çalışan önce kendini değerlendirmekte, sonra da yöneticisi çalışanı değerlendirmektedir. Sürecin sahibi ve sponsoru İK yöneticisi ise sürece koçluk yapmakta, sistem üzerinden akışı takip ederek sürecin doğru işlemesini sağlamaktadır. Kendini değerlendiren her bir çalışan, gerçekleşen verileri SAP üzerinden yöneticisine ve bölüm çalışanlarına sunmakta, sonra da performans verilerini üst yönetime sunmak üzere sistemdeki performans formuna işlemektedir. Daha sonra departman yöneticisi çalışanlarının bireysel hedeflerini ve iş/verimlilik hedeflerini sistem üzerinden değerlendirmektedir. Aralık Ayında yetkinlikler de değerlendirilmektedir. Her bir görev düzeyi için benimsenen yetkinliklerin altında, örneğin "destekleyici bir çalışma ortamı sağlar" gibi, spesifik davranışsal göstergeler, somut yetkinlik ölçütleri olarak tanımlanmıştır. Böylece yetkinlikleri ölçen davranışsal göstergeler adeta sözel standartlar olarak değerlendirilmiş olmaktadır. Yetkinlikler de değerlendirildikten

Performans Yönetiminde

Performans

Değerlendirme ve Öneri

Sitemlerinin Sürdürülebilir Verimliliğe Etkisinin Íncelenmesi: Bir Örnek Olay Çalışması 131 sonra sisteme hedef değerlendirme puanları ve yetkinlik puanları girilmekte ve böylece bireylerin $\mathbf{A}^{\prime}$ dan $\mathbf{D}^{\prime}$ ye performans göstergeleri oluşmaktadır: A: Çok üstün başarı; B: Beklenenin üzerinde; C: Başarılı; D: Yetersiz performansin göstergesidir. Bilgi sisteminde yer alan PKYS modülüne hedeflerle ilgili performans verileri ve yetkinlik puanları girildikten sonra çalışanın nihai performans göstergesi sistemde A, B, C, D şeklinde görülmektedir. Ayrıca sistemde çalışanın performans göstergesinin neden $A, B$, ya da $C$ veya $D$ olduğu da açıklanmaktadır.

PKYS Yönetmeliği: Doküman incelemesine göre, yukarıda açılanan performans yönetimi sisteminin aşamaları ve her aşamada gerçekleştirilmesi gereken işlemler, bu sistemin yönetmeliği olarak yazılmıştır. Yine, birbirini izleyen ve tamamlayan maddeler halinde sıralanan işlem adımları da sistemin süreç akış şemasını oluşturmaktadır.

Değerlendirme Periyodu: Örnek işletmede performans yönetimi bütün bir yıla yayılmaktadır. Süreç, Ocak Ayında planlama ile başlamakta; Temmuz Ayında ara değerlendirme yapılmakta; Aralık Ayı sonunda ise performans değerlendirme yapılmakta ve değerlendirme sonuçları ilgili yerlere ve yeni yılın stratejik planına veri aktarmaktadır. Yeni yılın başında yapılan planlamayla belirlenen ana hedeflere göre süreç yukarıda özetlendiği şekilde işlemektedir.

PKYS'de Kullanılan Yöntem: İşletmede hedef ve yetkinlik bazlı performans değerlendirme yöntemi uygulanmaktadır. Hedefler vizyondan, yetkinlikler ise şirket değerlerinden gelmektedir. Katılımcilara göre, "şirketi değerli kılan sadece sonuçlar değildir; değerler ve ilkeler de sonuçlar kadar önemlidir. Hedefler 
Performans

Yönetiminde

Performans

Değerlendirme

ve Öneri

Sitemlerinin

Sürdürülebilir

Verimliliğe

Etkisinin

İncelenmesi:

Bir Örnek Olay

Çalıșması

ne yaptı̆̆ınızı göstermektedir; yetkinlikler ise çalışma şeklinizi ve iş yapma tarzınızı davranış modeli olarak standardize etmektedir. Neyin yapıldığının yanında nasıl yapıldığı da önemlidir ve ölçülmelidir". Bu nedenle performans, yüzde 50 hedef; yüzde 50 yetkinlik olarak değerlendirilmektedir.

PKYS'nin İşletmeye ve Çalışanlara Katkısı: PYS, kaynakları, faaliyetleri ve sonuçları ölçüp değerlendirmektedir. İşletmede kullanılan tüm kaynaklar ve bu kaynakların kullanıldığı tüm faaliyetler bu ölçme-değerlendirme sistemi içerisinde yönetilebilir hale gelmektedir. Ayrıca yıl sonunda alınan değerleme sonuçlarına göre gelecek yılın hedefleri planlanarak; geçen yıla oranla daha düşük maliyetli, daha etkin ve daha hızlı süreç ve sonuç hedefleri konularak faktör verimliliğinde artış amaçlanmaktadır. Bu da örgütsel düzeyde işletmenin toplam verimliliğine doğrudan katkı yapmaktadır. Çalışanlar açısından ise; performans sisteminin işleyişinden bütün çalışanlar sorumludur ve hedefler belirlenirken çalışan işin içindedir. Performans değerlendirme sürecinde de çalışan "mutabakat" ilkesi gereği yine işin içindedir. Üstelik, sistemde çalışanların kendilerinin koyduğu bireysel hedefler de mevcuttur. Bu nedenle PKYS, performans sonuçları raporlandıktan sonra bütün organizasyonda herkesi bağlayan bir sistemdir ve sisteme dahil olan her çalışan, büyük resmin hangi noktasında katkısı olduğunu somut olarak görebilmektedir. Bireysel motivasyonu artıran bu durumda çalışan, daha yüksek bireysel hedefler koyabilmekte ve buna çabalamaktadır. Örgüt, süreç ve birey hedeflerini ve yetkinliklerini geliştiren PKYS, bu nedenlerden dolayı, işletmede stratejik bir yönetim aracı olarak kabul edilmektedir.

PKYS'de Geri-bildirimi ve Performans Sonuçlarnın Kullanılması Performans değerlendirme tamamlandiktan sonra performans sonuçları öncelikle kariyer planlamaya ve belli bir prosedüre göre işleyen ödül sistemine bilgi aktarmaktadır. Performansı çok başarılı ve beklenenin üzerinde olan A ve B düzeyindeki çalışanlara yükselme olanağı, ilave bir pozisyon ve ek sorumluluklar verilmekte ve bu sorumlulukları yerine getirebilmesi için gereken eğitimlerle desteklenmektedir. Performans göstergesi A, B ve C olanlara, ödül prosedürüne göre prim verilmektedir. Performans göstergesi $\mathbf{C}$ olana ise, hedeflerini gerçekleştirdiği için duyulan memnuniyet ifade edilirken; hangi konularda iyi olduğu, bunları daha da iyileştirebileceği, daha hangi konularda kendisinden başarı beklendiği ve kariyer gelişimini desteklemek için eğitim kataloğundan istediği eğitimi seçmesi yönetici tarafından bildirilmektedir. Performans göstergesi beklenenin altında yetersiz performans gösteren $\mathbf{D}$ düzeyindeki bir çalışan için ise "destek süreci" devreye girmekte ve yöneticisi çalışanla mülakat yaparak problemin ana kaynağını tespit etmektedir. Yöneticinin bu 
aşamadaki hedefi çalışanı kazanmaktır. Bu yaklaşımla performans düşüklüğünün kaynağı saptanıp, iyileştirme planı hazırlanarak uygulamaya alınmakta ve yönetici tarafından takip edilmektedir.

Performans yönetimi süreci sonunda ortaya çıkan bireysel performans düzeyleri kariyer gelişimi için somut, ölçülebilir ve objektif birer göstergedir ve aynı zamanda emeğin verimlilik artışını da yansıtmaktadır. İşletmede, çalışanların kariyer gelişimini destekleyen ve belli bir prosedüre göre işleyen bir ödül sistemi de mevcuttur. İK yöneticisine göre; "hedefleri organizasyonun tümüne yaymak, organizasyonu hizalandırmak ve bireysel/kurumsal verimliliği artırmak için performans yönetim süreci nasıl hayati bir süreçse, ödüllendirme sistemi de bu sürecin olmazsa olmazıdır". İşletme için ödül sistemi, kariyer gelişimini ve sürdürülebilir verimliliği destekleyen temel bir IKK uygulamasıdır. Performans yönetiminin birey/örgüt performanslarının geliştirilmesindeki önemini açıklayan katılımcılara göre; "Böyle bir sisteminiz olmaz ise; performans düzeyi $\boldsymbol{A}$ olanlar ile $\boldsymbol{D}$ olanlarn neye göre ayıklayabiliriz? Kariyer planın, somut bir gösterge olmadan neye göre yapabiliriz? Çalışanlarm ezberledikleri bir işte kendileri belirleyip benimsedikleri hedefler olmadan iyi bir performans ortaya koyabilmeleri zordur. Böyle bir sistem olmadan organizasyonun makro potansiyelini nasıl görebiliriz?

\section{3. Öneri Siteminin Anlamı ve Sürdürülebilir Verimlilik İle İlişkisi}

Çalışmaya konu olan örnek işletmede uygulanan mevcut öneri sisteminin adı Akıl Küpü Öneri Sistemi"dir (AKÖS). AKÖS, katılımcıların ifadesiyle; "hem Performans ve Kariyer Yönetim Sistemi, hem de Entegre Yönetim Sistemi için etkin araçlardan biridir". Bu nedenle, performans değerlendirmede KPI olarak yerini almıştır. Üst yönetim, kalite yönetimi sistemini oluşturma aşamasında çalışanların önerilerini almayı "çalışanların katılımının sağlanması" olarak yüzde yüz benimsemiştir. Bu sistem sayesinde çalışanların iyileştirme önerileri, ilgili formlar aracılığı ile sisteme yansıtılmakta ve önerilerden yararlanılmaktadır. Öneri sisteminin dayandığ1 ilke; "işi en iyi bilen o işi yapan kişidir" ilkesidir. İşi yapan kişilerin önerileri sayesinde öncelikle süreçlerde hataların ve kayıp sürelerin azaldığı görülmektedir. Kabul edilen öneri sayısı çalışanların kariyerleri ve yükselmelerinde önemli bir performans göstergesidir. Girdiler, çıktılar, süreç akışları, gıda güvenliği, iş güvenliği, çevre güvenliği, ergonomi ve tasarruf sağlayan bütün iyileştirme ve yenilik önerilerinin değerlendirilmesiyle verimlilik artışı sağlanmaktadır.

Öneri Sisteminin İşleyişi, Aşamaları ve Sorumluları: AKÖS, İşletmede süreç ve bölüm müdürleri dışında bütün çalışanların bireysel ya da takım halinde katılımına açık bir sistemdir. Sistem özetle şöyle işlemektedir: 
Performans

Yönetiminde

Performans

Değerlendirme

ve Öneri

Sitemlerinin

Sürdürülebilir

Verimliliğe

Etkisinin

İncelenmesi:

Bir Örnek Olay

Çalıșması

İşletmede; insan kaynakları, kalite, üretim ve bakım, bölümlerinden müdür, müdür yardımcısı, şef ve mühendis katılımıyla sekiz kişilik bir “Öneri Değerlendirme Kurulu" oluşturulmuştur.

Öneri sahibi ya da takımı önerilerini sistemdeki ilgili excel tablosuna girerek insan kaynakları müdürlügüne iletmektedir. Her hafta Cuma günü bu öneriler, akıl küpü değerlendirme toplantısında değerlendirilmektedir. Öneri hangi konuyla ilgili ise (gıda güvenliği, hijyen, kalite, makine verimliliği, bakım, vd), öneri değerleme kurulundaki ilgili kişi öneriyi cevaplandırmakta; uygulanabilir ya da uygulanamaz değerlendirmesi yapılmaktadır. Eğer öneri, kurulda üyesi bulunmayan bir uzmanlık alanını ilgilendiriyorsa ilgili kişi ya da birime (örneğin bir arıtma önerisi hemen çevre mühendisliğine iletilerek, değerlendirmesini öneri değerleme kuruluna göndermesi istenmektedir. Öneri değerleme kurulunda "uygulanabilir" bulunan her önerinin fayda-maliyet analizi yapilmakta ve öneri ile ilgili bölümün mühendisi veya uzmanı ile maliyet muhasebesi sorumlusu öneriyle ilgili bir maliyet raporu hazırlamaktadır. Maliyet avantajı sağlayacağ 1 değerlendirilen öneri maliyet skalasına göre ödüllendirilmektedir. Örneğin, birinci basamaktaki 1000-5000 TL maliyet avantajı sağlayan öneri altın, beşinci basamaktaki öneri kişisel bilgisayar ile ödüllendirilmektedir. Yapılan ödül töreninde bütün çalışanların katılımıyla öneri sahibi/sahipleri ödüllerini almaktadır.

\subsection{Araştırma Bulgularının Değerlendirilmesi}

Çalışmaya konu olan işletmenin vizyonu doğrultusunda temel stratejilerinden biri de faktör verimliliğini artırarak büyümektir. Bu bağlamda işletme için sürdürülebilir verimlilik, "ulusal bölgesel ve dünya pazarlarında yüksek kalite standartlarında ve rekabetçi fiyatlarla güvenilir gıda üreterek varlığını sürdürebilmek"tir. İşletmenin verimlilik anlayışına göre global piyasalarda rekabetin, yüksek kalitenin ve çevre dostu üretimin ön koşulu sürdürülebilir verimliliktir. İşletme, bütün süreçlerine, departmanlara, takımlara ve bireylere yayılmış olan verimlilik projeleriyle sürdürülebilir verimliliği genel yönetim sisteminin ana felsefesi ve operasyonel temel taşı olarak görmektedir.

İşletmede yüksek verimlilik ve kalite kültürü oluşturmayı hedefleyen PKYS, vizyonu ve ana hedefleri organizasyona taşıyan kilit bir yönetim uygulaması ve organizasyonun kariyer planlaması için de somut bir göstergedir. Organizasyonu oluşturan bireylerin, takımların ve süreçlerin sürekli iyileştirilmesi ve geliştirilmesi açısından stratejik bir yönetim süreci, aynı zamanda performans-ödül-disiplin dengesi açısından da temel bir İK uygulamasıdır. İK departmanının sponsorluğunda ve fakat bütün hat 
yöneticilerinin sorumluluğunda uygulanan süreç, bir taraftan örgüt, departman ve bireysel hedeflerle bağlantı kurarak dikey entegrasyonu sağlarken; diğer taraftan da İK (eğitim, ödül, motivasyon, kariyer vd) uygulamaları ile yatay entegrasyonu sağlamaktadır. Sistem, hem bireyin, hem de organizasyonun farklılığını ortaya koyan stratejik bir yönetim sürecidir. $\mathrm{Bu}$ süreçte neyin yapıldığının yanında nasıl yapıldığı da önemlidir ve ölçülmelidir. Bu nedenle örnek işletmenin performans sisteminde kullanılan yöntem, hedef ve yetkinlik bazlı değerleme yöntemidir. Hedefler vizyonu ve stratejileri; yetkinlikler ise kurumsal değerleri hayata geçiren performans standartları olarak ölçülmektedir.

\section{Tartışma ve Sonuç}

Örnek olay kapsamında yer alan işletmenin performans ve kariyer yönetim sistemi kurumsal performans, süreç/departman performansı ve bireysel performansı tek bir sistemde yöneten hedef ve yetkinlik bazlı PKYS'dir. Günümüzde giderek daha çok sayıda işletme de, performans değerlendirme çalışmalarını bireysel performans değerlemesi yerine, performans yönetim sistemi veya kurumsal performans yönetimi adi altında yürütmektedir (Armstrong, 2009; Uyargil, 2013). Bu çalışmada, faktör verimliliğini artırma projeleriyle sürdürülebilir büyümeyi hedefleyen bir süt ürünleri işletmesinin kendine özgü performans ve kariyer yönetim sistemi kapsamında gerçekleştirdiği bireysel performans değerlendirme ve öneri sistemleri ile sürdürülebilir verimlilik arasındaki ilişki ve etkileşimler incelenmiştir. Çalışma sonuçlarına göre, sürdürülebilir işletme olmanın temel işareti sayılan verimlilik artırma projelerinin ve bireysel verimlilik hedeflerinin hayata geçirilmesini sağlayan kilit sistemlerden biri de performans yönetim sistemidir. Bu süreçte stratejik amaçlar bireysel hedeflere indirgenmekte, sonra da sisteminin yıl boyu süren planlama, hedef gözden geçirmeleri ve performans değerlendirmeleri ile bireysel performanslar stratejik hedeflerle hizalandırılmaya çalışılmaktadır. Sürecin her aşamasında "hedef birliği" ve "ast-üst mutabakatı" esas alınmaktadır.

Araştırmanın sonuçlarına göre; verimlilik artırma hedeflerini ve bireysel performans değerlemesini kapsayan etkin bir performans yönetimi sistemi sürdürülebilir verimliliği pozitif yönde etkilemektedir Ancak bu sistemin başarılı olabilmesi için, TKY ve/veya ISO standartlarına uygun bir sistem olarak yapılandırılması ve öneri sistemi gibi sistemlerle de desteklenmesi uygun bulunmaktadır. Ayrıca, İşletmede bütün sistemleri, süreçleri, takımları ve bireyleri birbirine bağlayan ve eşzamanlı bilgi akışını sağlayan entegre bir yönetim bilgi sistemi ve bu sistem üzerinden çalışan raporlama, performans yönetiminin başarısı için kritik öneme sahiptir. Araştırmanın
Performans

Yönetiminde

Performans

Değerlendirme ve Öneri

Sitemlerinin

Sürdürülebilir

Verimliliğe

Etkisinin

Íncelenmesi:

Bir Örnek Olay

Çalışması

135 
Performans

Yönetiminde

Performans

Değerlendirme

ve Öneri

Sitemlerinin

Sürdürülebilir

Verimliliğe

Etkisinin

İncelenmesi:

Bir Örnek Olay

Çalıșması sonuçlarına göre, bireysel ve örgütsel performans değerlendirmeyi aynı sistem içerisinde gerçekleştiren ve aynı zamanda sürdürülebilir verimliliğe odaklı bir performans yönetim sisteminin etkinliğini sağlayan başlıca öneriler aşağıda sıralanmıştır:

- İşletmenin misyonu doğrultusunda stratejik planlama yapılmalı ve organizasyonel yön çalışanlarla paylaşılmalıdır.

- Stratejik plan doğrultusunda yıllık iş planları yapılarak o yıl odaklanılacak kritik performans alanları belirlenmeli ve bu alanlar ile ilgili kalite, maliyet, zaman ve hız hedefleri oluşturularak işletmenin yıllık bütçesi ile ilişkilendirilmelidir.

- Bu süreçte, sürdürülebilir verimlilik stratejisinin bir gereği olarak VAP hedefleri de (işgücü, hammadde, makine-ekipman, enerji verimliliği hedefleri) ve varsa bireysel verimlilik önerileri sistemde verimlilik hedefleri olarak yer almalıdır.

- Hedefler bölüm/departman müdürlerine dağıtılarak hedef dağılımları yapılmalı; departmanlarda da bireysel hedefler belirlenmelidir.

- Sistem geliştirilirken aynı zamanda işletmenin iş ve yönetim süreçleri de dikkate alınarak ana veya alt süreçlerin ya da kilit/kritik süreçlerin performans göstergeleriyle kurum, departman ve bireysel hedefler birbirleriyle uyumlaştırılmalıdır.

- Çalışanların sürece aktif katılımı sağlanmalı; hedef birliği, sürekli diyalog ve mutabakat esas olmalıdır.

- Performans yönetimi sistemi, her aşamada performans bilgisinin paylaşımını, sürekli performans takibini, geri-beslemeyi ve raporlamayı sağlayan etkin bir bilgi sistemi üzerinden yürütülmelidir.

- Performans yönetimi yönetmeliği ya da prosedürü hazırlanmalıdır.

- Performans değerlendirmenin kapsamı ve yöntemi tanımlanmalıdır.

- Yöneticiler, örgütün yıllık hedeflerini süreç, departman ve birey hedeflerine indirgeme konusunda bilgili ve deneyimli olmalıdır.

- Çalışanların motivasyonu, performans iyileştirme, eğitim ve kariyer planlama süreçlerinde yüz-yüze ve sistem üzerinden geri-besleme yapilmalıdır. 
- Hedefler yönünde ilerleme, gelişimsel destek ve koçluk konularında değerleyen (yönetici) ile değerlendirilen (astlar) arasında etkin iletişim ve işbirliği desteklenmelidir.

- Organizasyonda benimsenen performans değerlendirme yöntemine uygun bir performans puanlaması yapılmalıdır.

- Organizasyona özel performans değerleme formları ve raporlama sistemi geliştirilmelidir.

- Bireysel başarının tanınması ve ödüllendirme bir prosedüre bağlanmalıdır.

- Çalışanların kalite iyileştirici, müşteri memnuniyeti ve verimlilik artırıcı nitelikteki fikirlerinin etkin bir şekilde değerlendirilmesini sağlayan bir öneri sistemi kurulmalı ve sisteme entegre edilmelidir.

Bu çalışmaya konu olan işletmenin sınıfında iyi uygulama örneği olan iki sistemi; Performans ve Kariyer Yönetim Sistemi ve Akıl Küpü Öneri Sistemi, yerinde incelenerek, sürdürülebilir verimlilik ile ilişkileri ve verimliliğe etkileri betimlenmiş ve sistemlerin nasıl çalıştığ Çalışma, örgütsel ve bireysel performansı ve işgücü önerilerini tek bir sistemle planlayan, ölçen, değerlendiren ve geliştiren bir performans yönetimi uygulamasıyla sürdürülebilir verimliliği ilişkilendirerek literatüre katkı sağlamaktadır. Uygulayıcılar açısından çalışmanın katkısı ise, verimlilik temelli bir performans yönetim sistemi kurmak isteyen veya sistemini iyileştirmek isteyen işletmeler için performans yönetimi sürecinin uygulama adımları; altyapısı, öncesi, sonrası vd. bağlantılı konularda kendilerine uyarlayabilecekleri ayrıntılı bilgi ve açıklamalar getirmesidir.

Sürdürülebilir verimlilikle doğrudan bağlantılı olan sürdürülebilir işletme, sürdürülebilir çevre, sürdürülebilir doğal kaynaklar ve sürdürülebilir enerji toplumun tüm kesimlerini her zamankinden daha çok ilgilendiren konulardır. İşletme düzeyinde başarılı performans yönetimi, performans değerlendirme ve öneri sistemi uygulamalarını sürdürülebilir verimlilik ile ilişkilendirerek derinlemesine inceleyen çalışmalara ihtiyaç vardır. Konuyla ilgili daha geniş bir anlayışa varmak için bu çalışmaların, farklı işletmelerde, daha geniş bir zaman diliminde ve daha fazla araştırmacı ve katılımcı ile yapılması hem araştırmacılar hem de uygulayıcılar açısından daha yararlı sonuçlar sağlayacaktır.

\section{Kaynakça}


Performans

Yönetiminde

Performans

Değerlendirme

ve Öneri

Sitemlerinin

Sürdürülebilir

Verimliliğe

Etkisinin

İncelenmesi:

Bir Örnek Olay

Calıșması

Adal, Z. (2009), İnsan Kaynakları Yönetimi. İçinde, C. Uyargil, vd (Ed), “İnsan Kaynakları Yönetiminin Hukuki Boyutları", s. 491-606, İ.Ü.İşletme Fakültesi, Yayın No:2211, İstanbul.

Aguinis, H. (2014). Performance Management, (Third Edition), Pearson Education Limited, U.K.

Akal, Z. (2011). İşletmelerde Performans Ölçümü ve Denetimi, (7.Basım), MPM Yayın1, No:473, Ankara.

Altunışık, R., Coşkun, R, Bayraktaroğlu, S. ve Yıldırım, E. (2004), Sosyal Bilimlerde Araştırma Yöntemleri, (3. Baskı), Sakarya Kitabevi, Sakarya.

Arçelik, (2014). "Arçelik Sürdürülebilirlik Raporu”, http://www.arcelikas.com/ , 27.03.2015.

Armstrong, M. (2009). Armstrong's Handbook of Performance Management: An Evidence Based Guide to Deliver High Performance, (4.Ed), Kogan Page, London.

Atılgan, T. (2002). “Konfeksiyon İşletmelerinde Performans Değerlendirme ve Etki Eden Faktörler", Türkiye V. Pamuk, Tekstil ve Konfeksiyon Sempozyumu, Diyarbakır.

Atlas COPCO (2009). "Sustainable Productivity", http://www.atlascopco.com/us/AtlasCopcoGroup/Productivity/ e.t.27.03.2015.

Baxter, P., Jack, S. (2008). Qualitative Case Study Methodology: Study Design and Implementation for Researchers: The Qualitative Report, 13 (4), December, 2008, 544-559.

Bingöl, D. (2014). İnsan Kaynakları Yönetimi (9. Basım), Beta, İstanbul.

Borusan, (2014). "Borusan Sürdürülebilirlik Raporu", http://www.kurumsalsurdurulebilirlik.com.tr/raporlar/borusansurdurulebilirlik/27.03.2015.

Chen, S.Y, Uen, J.I ve Chen, C.C. (2016). “Implementing High Performance HR Practices in Asia: HR Practices Consistency, Employee Roles and Performance", Asia-Pacific Journal of Management, 33 (4), 957-958.

Chubb, C., Reilly, P., ve Brown, D. (2011). Performance Management: Literature Review, Institute for Employment Studies-IES: The IES HR Network, UK.

Çalışkan, E. N, (2010). "The Impact of Strategic Human Resource Management on Organizational Performance", Journal of Naval Sciences and Engineering, $6(2), 100-116$.

Çömlek, O. (2009). Özdeğerlendirme ve Verimlilik Analizi Yoluyla Performans Değerlendirmeye Bir Model Önerisi, Gebze Yüksek Teknoloji Enstitüsü, Sosyal Bilimler Enstitüsü, Doktora Tezi, Gebze. 
DelCampo, R.G. (2011). Human Resource Management, McGraw Hill, N.Y.

Dessler, G. (2011), Human Resource Management (12.Ed ), Pearson Education Inc, N.J.

Dessler, G. (2013). Human Resource Management, (13. Ed), Pearson Education Inc, N.J.

Dorgan, S. J. Dowdy, J. J, ve Rippin, T.M. (2006). “The Link Between Management and Productivity", McKinsey Quarterly Publishing, February, 2006, 5-13.

Duchon, M. (2007). "Improve Productivity with Performance Evaluations", http://www.constructionbusinessowners.com/topics/management/construc tion-workforce/management/improve-productivity-performanceevaluation/, 05.12.2014.

Eksen, H. (2010). "Milli Prodüktivite Merkezi, Denizli Verimliliği Artırma Projesi", http://www.dso.org.tr/userFiles/File/Verimlilik toplam kalite2.pdf/, 05.05.2010.

Forfas - Ireland Policy Advisory Board for Enterprise, Trade, Science, Technology and Innovation,(2009), "Boost Your Company's Productivity", http://www.forfas.ie/ , 05.12.2014.

Grote, D. (2002). The Performance Appraisal Question and Answer Book: A Survival Guide for Managers, AMACOM, NY.

Hekimci, F. (2012). “ Sürdürülebilir Yarınlar İçin Sürdürülebilir Tüketim ve Enerji Verimliliği" Anahtar Dergisi, Yı1:24, Sayı:277, Ankara, 10-15.

Hesapro (Health and Safety at Work in Relation With Productivity), (2013). Background Research Paper, Lifelong Learning Programme, Hesapro Partners, April 2013, 1-32. http://www.hesapro.org/files/BackgroundResearch-tr.pdf/ , 23.01.2017.

Huselid, M, A. (1995). “The Impact of Human Resource Management Practices on Turnover, Productivity and Corporate Financial Performance", Academy of Management Journal, 38, 635-672.

İslamoğlu, A, H., Alnıaçık, Ü. (2014). Sosyal Bilimlerde Araştırma Yöntemleri (4.Bask1), Beta, İstanbul.

Koç, A. (2009). "Verimliliğe Dayalı Büyüme”, Tisk, İşveren Dergisi, Eylül 2009, Ankara.

Kontoghiorghes C., Gudgel R. (2004). "Investigating the Association Between Productivity and Quality Performance in Two Manufacturing Settings", Quality Management Journal, 11 (2), 8-20.

Mitchell B, Gamlem C. (2012). The Big Book of HR, Career Press, New Jersey.

Milli Prodüktivite Merkezi-MPM VAT Dizisi, (1999). “Verimliliği Artırıcı Yaklaşım ve Teknikler Dizisi", MPM, Ankara.
Performans

Yönetiminde

Performans

Değerlendirme ve Öneri

Sitemlerinin

Sürdürülebilir

Verimliliğe Etkisinin İncelenmesi:

Bir Örnek Olay Çalışması

139 
Performans

Yönetiminde

Performans

Değerlendirme

ve Öneri

Sitemlerinin

Sürdürülebilir

Verimliliğe

Etkisinin

İncelenmesi:

Bir Örnek Olay

Çalıșması

Milli Prodüktivite Merkezi-MPM, (2004). "Sürdürülebilir Büyümenin Anahtarı Verimlilik" http://www.mpm.org.tr/ , 02.05.2010.

Neuman, W.L. (2014). Social Research Methods: Qualitative and Quantitative Approaches, (seventh Edition), Pearson New International Edition, London.

Özbek, Ç.( 2007). Verimlilik Artırma Teknikleri, Yüksek Lisans Tezi, Yıldız Teknik Üniversitesi, Sosyal Bilimler Enstitüsü, İstanbul.

Özen, G. (2008). Küresel Isınma Sürecinde Örgütsel Performansın Sürdürülebilir Kılınması Açısından İşletmelerde Eko Verimlilik Çalışmaları: Örnek Uygulamalar, YL Tezi, Selçuk Üniversitesi, Sosyal Bilimler Enstitüsü, Konya.

Peşkircioğlu, N. (2014). "Verimlilik Yönetimi", Anahtar Dergisi, Haziran 2014, Sayı.306.

Peşkircioğlu, N., Frolet, İ. ve Çil, F. (2013). “Kurumsal Performansı Artırmanın Bir Yolu Olarak İş Sağlı̆̆ı ve Güvenliği", IV. Ulusal Verimlilik Kongresi, 10-12 Aralık, 2013, Ankara.

Prasetya, A., Masanori, K. (2010). “Correlation Among Productivity, Performance Assessment System and Salary System (A numerical Representation of A Qualitative Survey), Research Journal of International Studies, Issue: 16, 84-103.

Prokopenko, J, North, K. (2011). Verimlilik ve Kalite Yönetimi: Modüler Program, Cilt1, 2, T.C. Bilim, Sanayi ve Teknoloji Bakanlığı, Verimlilik Genel Müdürlüğü Yayını, Yayın No:716, Ankara.

Prokopenko, J. (1992). Verimlilik Yönetimi: Uygulamalı El Kitabı (Çeviri: O, Baykal, . N. Atalay ve E. Fidan), MPM Yayını, No:476, Ankara.

Prokopenko, J. (2006). Verimliliği Teşvik Kuruluşları: Evrim ve Deneyim (ILO Verimlilik ve Yönetim Geliştirme Programı), 675. Cilt, MPM Yayınları, Ankara.

Sabuncuoğlu, Z. (2008). İnsan Kaynakları Yönetimi, (3. Baskı), Alfa Aktuel Basım, Bursa.

Sahu, R, K. ( 2007). Performance Management System, Excel Books, New Delhi.

Saratun, M. (2016), "Performance Management to Enhance Employee Engagement for Corporate Susutainability",Asia-Pacific Journal of Business Administration, 8 (1), 84-102.

Sarıaltın, H. (2003). Örgüt Performansının Ölçülmesi ve Geliştirilmesinde Kıyaslama Yöntemi ve İmalat Şirketlerinde Kıyaslama Uygulamaları, Yayınlanmamış Doktora Tezi, Sakarya Üniversitesi, Sosyal Bilimler Enstitüsü, , Sakarya. 
Sarıaltın, H., Yılmazer, A. (2011). "İşletme Düzeyinde Bir Verimlik Yönetim Sisteminin İncelenmesi: Bir Süt ve Süt Ürünleri İşletmesi En İyi Uygulama Örneği", 16. Dünya Verimlilik Kongresi ve Avrupa Verimlilik Konferansi, Bildiriler, 1.Cilt-Part.1, Mayıs, 2011, Ankara, 72-86.

Speziale, M. T., Kloviene, L. (2014). "The Relationship Between Performance Measurement and Susutainability Reporting: A literature Review", Procedia-Social and Behavioral Sciences, 156, November, 2014, Elseiver, 633-638.

Subramaniam, V. (2010). Productivity İmplications of Performance Appraisal System: Innovative Link Between Productivity and Performance Appraisal of Manpower, (Applicaple to All World Organizations) Lambert Publishing, India.

Tangen, S, 2005., "Demystifying Productivity and Performance", International Journal of Performance Management, Emerald Group Publishing, 54 (1), 34-46.

Tümer, S. 2007. “Kurumsal Performans Yönetim Sistemi, MPM İK Bölümü Eğitim Programı", http://www.mpm.org.tr/ , 10.02.2010.

Uyargil, C. (2013). Performans Yönetimi Sistemi, (3.Baskı), Beta, İstanbul.

Uyargil, C. (2009). İnsan Kaynakları Yönetimi İçinde, Cavide Uyargil, vd (Ed), "Performans Değerlendirme", s.209-259, İ.Ü, İşletme Fakültesi Yayın No: 2211, Beta, İstanbul.

Verimlilik Genel Müdürlüğü (2012). Verimlilik ve Kalite Yönetimi Modüler Program, Cilt:1, T.C. Bilim, Sanayi ve Teknoloji Bakanlığı, Ankara.

World Confederation of Productivity Sciences-WCPS, (2012). http://www.wcps.info/wordpress/wpcontent/uploads/2012/08/Congress.Arvhive.pdf/

Yıldırım, A. Şimşek, H. (2005). Sosyal Bilimlerde Nitel Araştırma Yöntemleri, Seçkin Yayınevi, Ankara

Yılmaz, F, (2006). Performans Değerlendirme Sisteminin İşletme Verimliliği Üzerine Etkisi ve Örnek Bir Uygulama, Trakya Üniversitesi, Sosyal.Bilimler.Enst, YL Tezi, Edirne.

Yin, R. K. (2011). Qualitative Research from Start to Finish (1. Ed), The Guilford Press, N.Y.

Zaman, A. (2011). “A Critical Review of Performance Management and its Impacts on Productivity: A Case of TRM Pakistan" http://www.ssrn.com/sol3/papers-cfm?abstract id=2135338/ 29.03 .2014 .

Yüksel, Ö. (2003), İnsan Kaynakları Yönetimi, (3. Baskı), Gazi Katabevi, Ankara.

\section{Performans \\ Yönetiminde \\ Performans \\ Değerlendirme ve Öneri \\ Sitemlerinin \\ Sürdürülebilir \\ Verimliliğe \\ Etkisinin \\ İncelenmesi: \\ Bir Örnek Olay \\ Çalışması}

141 